\title{
Elderly Care - A Case for the CSR Initiatives
}

\author{
George Abraham Kurian
}

Director, Vitalsource Knowledge Associates Private Ltd., Kerala, India

\begin{abstract}
Elderly Care is a grossly underserved area in India, which is home to one-sixth of the global population. Growth in the elderly population is showing a rising trend both globally and in India. By 2050 the total population of elders is projected to exceed 300 million and is likely to change India's status as world's youngest country by 2020 (average age of an Indian is 29 years). Elderly Care becomes more relevant in India as social security and affordable healthcare of acceptable quality are not accessible to the majority of Indians. Women in rural areas are the most vulnerable class among the elders. Breakdown of the joint family system, preference for nuclear families and trend of many younger Indians to stay far away from parents, poses serious challenges specifically for those elders with lesser financial means and the more aged among the elderly. India while recording very impressive GDP growth over the past few years has been unable to effectively address income inequalities. The economically lesser privileged elders are harder hit due to such income inequalities and the majority find it increasingly difficult to earn a decent livelihood amidst the rise in healthcare costs.
\end{abstract}

The objective of this article is to:

$>$ present some major issues facing the Elderly,

$>$ its repercussions,

$>$ steps taken to address the issues, and

$>$ suggest possible remedies to effectively manage it.

Though the issues discussed are relevant to Elderly care in a global context, the Article specifically focuses on India and includes a case study of the state of Kerala. It emphasizes the need and highlights opportunities where companies through Corporate Social Responsibility (CSR) can significantly contribute to this burgeoning problem of ageing that may pose major challenges to countries if not suitably addressed.

Keywords: elderly care, corporate social responsibility, Sustainable Development Goals, Millennium Development Goals, joint family system, the Maintenance and Welfare of Parents and Elderly Citizens Act.

JEL Classification: J14, M14, Q01.

(C) The Author, 2018. This article is published with open access at Sumy State University.

\section{Introduction}

Countries worldwide, stand united today in addressing several chronic social and ecological issues plaguing mankind like poverty, food shortage, pollution, eradication of diseases, employment generation, gender bias etc. Besides achieving a global consensus on how to tackle such issues, several of the agreed courses of action have specific benchmarks established by UN agencies through Millennium Development Goals (MDGs) earlier and Sustainable Development Goals (SDGs) currently. These goals enable monitoring and help countries to address specific issues through targets and timeframes aimed to control these effectively and proactively, depending on how such issues affect each of these countries.

While progress made through MDGs and SDGs are commendable especially at country-specific level, there is no specific MDG/SDG for Elderly care, but some of the SDGs indirectly support Elderly care and seem to address issues relating to the ageing population. The elderly population is growing at a faster rate globally as compared to fertility rates and this is bound to have wide ramifications if not properly handled. For instance, SDG-3 closely related to healthy ageing states: "To ensure healthy lives and promote well-being for all at all ages through universal health coverage including financial risk protection".

Initially, the areas falling within the ambit of Corporate Social Responsibility (CSR) in India were largely fashioned around the eight MDGs that did not include any reference to support for senior citizens. While the list of possible areas of support is long, the following have more direct relevance to senior citizens:

Eradicating hunger, poverty and malnutrition, promoting preventive health care, sanitation and safe drinking water; 
Promoting education, including employment enhancing vocational skills especially among children, women, elderly and other livelihood enhancement projects;

Promoting gender equality;

$>$ setting up homes and hostels for women and orphans;

$>$ setting up old-age homes, day care centers and such other facilities for senior citizens, and

measures for reducing inequalities faced by socially and economically backward groups.

Analysis of UN statistics and other reliable sources including The World FactBook over the ten year period 2008-2017 indicates that while global life expectancy rates are steadily going up on a year-on-year basis, maternal and infant mortality rates are going down, literacy rates and quality of healthcare indices are improving albeit at varying rates depending on the level of development achieved by each country. Due to these trends, the population is increasing at faster rates especially in the developing countries. These factors indicate changing trends in the elderly segment of the population, that poses new challenges to governments and have to be decisively as well as comprehensively addressed at country-specific levels, through appropriate monitoring mechanism.

According to United National Population Fund (UNFPA), Elderly citizens, meaning those above the age of 60 today, comprise around $12 \%$ of current global population of 7.3 billion and is projected to touch $22 \%$ ( 2 billion) by 2050 , which for the first time in history, will outnumber the population under 15 years of age.

According to Age International, UK (an NGO engaged in supporting vulnerable older people in developing countries), today 982 million people worldwide are aged over 60 , out of which $62 \%$ of the elderly people live in a developing country. By 2050, this number is expected to rise to 80\% (World Health Organization, 2018). The whole globe is experiencing a demographic shift, even in the poorest and least developed countries.

In the Indian context, such elderly citizens constituted $7.5 \%$ of the Indian population (104 million) as per the last census of 2011 , which is estimated to rise to $12.5 \%$ by 2021 (143 million) and to $20 \%$ (300 million) by 2020. (Helpage India Ageing Report, 2017).

The India Ageing Report 2017 sets the tone, by stating that "Ageing does not just affect the Elderly; it affects everyone in society in one way or the other".

\section{All is Not Well for the Elderly}

More than 180 million older people live in poverty; of those, 100 million live on less than 60 pence a day, which means they cannot afford enough food, healthcare or shelter for subsistence (Age International, UK). In this context, a few relevant facts are noteworthy:

Only 25 percent (one in four) of older people in developing countries receive a pension, so vast numbers need to work until the day they die.

$>$ Healthcare is unaffordable, inaccessible or inappropriate for many in the developing world, particularly in rural areas.

$>$ Health insurance coverage is available only to $27 \%$ or 350 million of the Indian population (National Health Profile Report, 2017).

$>$ Older people routinely face age discrimination. Many people in later life are refused work, medication or loans because they are considered to be 'too old.'

$>$ When disasters strike, people in later life are among the most vulnerable to death, injury and disease.

> Many people in later life in developing countries are also caring for grandchildren orphaned by AIDS, famine or conflict.

Elders face several challenges in life, especially during their ageing years when earning sources dry up for many and financial resources, fall short of generating sufficient cash flows to meet their personal needs that include an increasing component of healthcare costs. Changing demographic profile characterized by the rise in the number of elderly people has thrown up many new challenges in the social, economic and political domains.

Many of the older people in developing countries have lived their entire lives in poverty. As they get older, age-related health problems and ageism make it even more difficult for them to survive. Such Elderly in need should be helped, no matter what age they are.

Status of Elders is different in the urban and rural areas of India. Women in rural areas of India are the most vulnerable as the majority of them are illiterate, do not have any significant asset, nor the source of income of their own, tend to outlive their husbands and may be regarded as a liability as they get older. 
The trend in migration from rural to urban areas has been mainly among the younger population leaving the elderly in the villages alone and unattended. Physical ailments like musculoskeletal problems, poor vision and sleep disorders are accompanied with a high prevalence of neuropsychiatric disorders - (Providing Services for Elderly in Rural India - Is Anganwadi Centres a feasible option? - Dr Sonali Sarkar, Intl. J. Public Health-2016).

\section{The Kerala Context}

As a brief background, the southern Indian state of Kerala is the most literate state in India and has a population of around 334 million. It is demographically the $12^{\text {th }}$ ranked State in India (Census of India, 2011) and is home to $3 \%$ of India's population of 1.29 billion (Estimate of 2017).

Blessed with tropical climate, fertile soil and a vast coastal belt, the breath-taking beauty of its backwaters due to its crisscrossing rivers and streams, lush green expanse of hilly terrain dotted with coconut palms, banana trees, rubber and tea plantations, the State is a tourist's paradise, which has earned it the enviable label of "God's Own Country". It is predominantly a consumer-oriented state, due to which retail industry and services like education and healthcare do well and governmental organizations make up a substantial percentage of the business and governmental activities of Kerala.

The State's industrial sector is relatively quite small and is primarily agro-based, with very limited manufacturing activity. This is partly attributable to its literate masses, whose political leanings and militant trade unionism, has rendered the State less attractive for business enterprises.

Kerala, however, continues to dominate and retains its No.1 ranking in various social indices like Education, Healthcare, Social Security, Welfare of Women and Children, Gender Equality, Law and Order, Environment, Transparency and Accountability, Infrastructural facilities and Deliverance of Justice (Public Affairs Centre, 2018).

Due to the high level of wages in the State, agricultural activities and agro-based industries tend to become relatively less financially viable and the production yield is unpredictable as it is subject to vagaries of nature. Small to medium businesses in particular, do not find it attractive compared to several other states in India, to set up ventures and facilities in the State, given the mediocre level of governmental support, delicate power situation (mainly dependent on hydal power which is subject to the level of rainfall), high costs and comparatively low financial incentives offered. Further, owing to the relatively higher level of literacy, new job entrants nurture high career expectations, due to which the State finds it progressively difficult to ensure gainful employment for its increasing number of young job seekers.

According to the Fifth Annual Employment-Unemployment Survey 2015-16, the State's unemployment level is the highest among major states in India at $12.5 \%$ as compared to the national average of around 5\%. Unemployment among youth, who constitute $23 \%$ of the State's population, is $21.7 \%$ in rural areas and $18 \%$ in urban areas. Similarly, the unemployment rate among the young females, even though found to be well educated is much higher than that of the young males (Times of India, 2 Feb 2018). This is paradoxical considering that Kerala tops in literacy among major states.

In the above scenario, the younger and middle age population tend to migrate to other states and a large number of them seek education and employment overseas. The Middle East countries and in recent years, the western countries have seen a large influx of Indians, especially from Kerala taking up jobs mainly involving professional and technical skills. Consequently, the present mix of the population comprises a higher percentage of students and elderly citizens as compared to other states in India.

As compared to India's Gross State Domestic Product (GSDP) of US\$1,600 in 2016-17, Kerala had a GSDP per capita of US\$2,700, which ranks in the top 5 among major states.

In comparison with the ratio of Elders forming $7.5 \%$ in the Indian population, Kerala's elderly population is $12.6 \%$ of the State's population. This is partly attributable to the better quality of life, as several of Kerala's human scores and development indices and overall health indicators compare favorably with that of developed countries.

Of the total population of Kerala of around 350 million, the proportion of aged population increased from $10.5 \%$ in 2001 to $12.6 \%$ in 2011 and the proportion of $80+$ population in the total population increased from $11.7 \%$ in 2001 to $12.9 \%$ in 2011 (Census 2011). The pace of population ageing in Kerala is very fast, which has turned the State into an ageing society. Kerala is also known for its high levels of out-migration, a factor that might have contributed to the high proportion of the elderly as compared to youth.

Kerala still has the highest overall life expectancy at birth at 74.9 years -72 for men and 77.8 for women in 2010-14 period, as against the India average of 67.9 years -66.4 for men and 69.6 years for male and females. 
This implies that elderly people live to a higher age in Kerala, thus calling for increased attention to providing support for the elders in the State. Another noteworthy aspect is that the life expectancy levels in Kerala do not have a significant difference at 77.1 for urban and 78.1 for rural. Similar comparables for India overall are 73.2 for urban and 68.4 for rural (Human Development Index Report, UNDP and Registrar General of India's SRS (Sample Registration Survey) - 2016).

The elderly citizens in Kerala face some generic and certain unique challenges, which are discussed as a case study in this submission.

In the Indian scenario, family care is an integral part of the old age care. Given the context of ageing in Kerala, a living arrangement of the elderly has an important role to play in their care. In particular, in this era of increasing longevity, there is a likelihood of a rise in the cost of providing care for the elderly. A family is the most cherished social institution in India and the most vital non-formal social security for the elderly (Central Statistical Organization, 2006). In recent years, many changes have occurred in the family system that adversely affects Elders.

$>$ The most crucial and preferred aspect of living arrangements for the elderly is co-residence with adult children in extended families or multigenerational households where kind provide income, personal care and emotional support to the elderly (Irudaya Rajan \& Kumar, 2003).

$>$ In India in general and in Kerala in particular, families have traditionally supported elderly persons. In Kerala, only 3.1 percent of the elderly are living alone in their houses. Among them, the 70-79 age group (4 percent) comprise the major section.

$>$ It is often seen that a healthy and earning elderly member is always considered an asset; while on the other hand, bedridden and fully dependent parents may be regarded as a liability even by their own children.

> The elderly, who have adequate financial resources and take care of family affairs, who are productive and involved in income generation activities and contribute to the family, are looked after well and held in good esteem by the young.

After 1971, there has been a gradual decrease in the population growth rate, along with an increase in the growth rate of the elderly. Though Kerala has registered an impressive annual exponential growth of 0.5 percent in 2011, its elderly population is growing at a perpetual rate of 2.3 percent. The growth rate is high among the elderly aged 70-80 and above. In other words, along with the declining growth rate of the population, the proportion of elderly in Kerala is increasing over the years (S. IrudayaRajan and U. S. Mishra of Centre for Development Studies (CDS)).

Factors like a very low level of state pension, a declining trend of interest income on savings, increasing cost of living, rising cost for quality healthcare, limited scope for gainful employment, higher life expectancy, children living away from parents or not supporting them, breakdown of the undivided family system and preference for nuclear families, all serve to aggravate the problems of the elderly citizens living in Kerala.

While various NGOs and religious denominations are doing commendable work in serving the aged destitute through their charitable institutions, the concept of elderly living has not yet gained traction in the State. Ageing parents and in many cases their children still find it below their dignity to stay in such elderly homes and partly because such elderly homes are offering facilities suitable to the middle class and upper economic classes and affordable homes providing caregiving services of minimum acceptable standards, are still limited.

Latest statistics indicate that Kerala state has 714 elderly living homes, which is higher than any other state in India and is home to 18000 Elderly citizens. This number seems quite minuscule when viewed against its 4 million elderly population (Indian Express, 2018). This indicates that the elders or their family members still don't prefer taking up this option of staying in Elderly homes, whether state-run or otherwise.

\section{Key Issues Faced by the Elderly}

Some of the key issues faced by the ageing population in India and Kerala specifically are set out below:

\section{Lesser disposable income for meeting financial needs:}

Elders as they age, tend to have lesser earning potential through employment or by carrying on a business or profession. The financially better off elders earn through passive income from investments or property. In the lower economic strata, elders are forced to earn their daily bread by working for wages or through small trade.

Historically, barring the minority who are in the affluent class, the monthly disposable income of Elders is more likely to reflect a declining trend, whereas the cost of living keeps increasing, due to inflationary pressures, higher health care costs and a declining trend noted in the yield on their savings/investments. 
In the absence of a reliable social security system and an insufficient public healthcare system, a majority of Elders in the country today, find it difficult to make ends meet. Uncertainties of health which may result in huge unanticipated medical costs for meeting surgery and curative treatment costs may further deplete available savings. Not having an appropriate mix of insurance products in one's investment portfolio, may prove detrimental in many cases, as those covered by health Insurance in India are still confined to around $27 \%$ of the population (National Health Profile, 2017) mainly comprising of economically middle and upperclass Elders. Government schemes have recently made some progress to reach life and accident insurance to the poorer section

\section{Pension entitlement limited to a small percentage of Elders:}

Only Central and State Government employees and those working in semi-government organizations, public sector companies, banks, MNCs and larger private companies, are eligible for pension on retirement. As per the Kerala Ageing Survey 2013, only $36.44 \%$ of the elderly receive a pension from the government (S.Irudaya Rajan - Gayathri Balagopal - Elderly Care in India - Societal and State Responses, 2017).

Elderly pension under NSAP: Under the Indira Gandhi National Old Age Pension Scheme, Central assistance is given towards pension at Rs. 200/- per month - persons above 60 years and at Rs. 500/- p.m to persons above 80 years belonging to a household below the poverty line. States are supposed to make equal to these beneficiaries. This amount totaling less than Rs. 1500 is quite low to meet basic subsistence costs but can provide some relief to supplement the income of the poor especially in rural areas.

\section{Disproportionately high mix of illiquid assets:}

Most middle and upper-class elders hold a large proportion of their assets as land and building, which are illiquid and earns very low, yield (2-3\% for residential property let out and 6-7\% for commercial property) as they tend to consider such wealth as more secure. Such assets are less likely to be disposed in case of a need, given its form and nature, sentimental reasons or due to pressure from children on whom the elders may be directly or emotionally dependent.

Reverse Mortgaging which is an innovative means for elders to raise incremental funds from banks or financial institutions as a stream of inflows by mortgaging of a residential property is a popular means for Elderly citizens to augment fund sources, for meeting monthly subsistence costs. While this system of generating liquid funds out of such illiquid assets, is well established and used beneficially by elders in several developed countries, it has not gained traction in India yet, though introduced by some banks almost a decade back, mainly due to unreasonable borrowing terms and general aversion of elders to mortgaging their residential house which is considered a social stigma.

\section{Unanticipated financial difficulties, due to miscalculating retirement needs:}

Elders in many cases would have underestimated their life expectancy, and live longer due to better quality of life, better access to healthcare etc. and hence the retirement savings and wealth may not suffice to cover their subsistence needs, maintain lifestyle and meet unpredictable healthcare costs that tend to income due to higher susceptibility to illnesses and accidents as gets older.

To remedy the above situation, Government of India through its various ministries has provided some privileges for Elderly citizens as cited below:

$>$ Ministry of Finance offers health insurance programmes up to the age of 65 years.

$>$ Several tax incentives are made available for Elderly citizens and very Elderly citizens under the prevalent tax laws. These include higher basic income tax exemption limit for both Elderly citizens (up toRs. 300,000 per annum and for 80+ Elders up to Rs.500, 000 p.a).

$>$ The higher rate of interest income in Government Saving Schemes and on bank deposits.

$>$ The deduction is also allowed for medical insurance and for treatment of a dependent Elderly citizen suffering from specified diseases.

$>$ Ministry of Railways and Civil Aviation provides concessional fares for Elderly citizens. Air India, the local public sector carrier, has permitted 50\% deduction in airfare for Elderly citizens.

Chapter V of the Maintenance and Welfare of Parents and Elderly Citizens Act, 2007 which comes under the Ministry of Domestic Affairs, also provides for protection of life and property of Elderly citizens (provisions of this statute are highlighted in detail below).

Elders who are in good health and in financial need should try to earn and supplement their income or develop skills to take up new income generating activities and augment earnings. 


\section{Shortcomings in Care Giving responsibility to Elders:}

HelpAge India, which is the leading NGO in the country dedicated to supporting the cause of the elderly, has been conducting several surveys targeting the Elderly, over the past several years. This year's Survey (HelpAge India, 2018) on Elder Abuse was conducted in 23 cities of India by interviewing elderly above 60 years of age. Some excerpts from their research are as follows:

$>73 \%$ of youth accept Elder Abuse exists.

$>34.7 \%$ of youth perceive the primary abuser to be the daughter-in-law and $23 \%$ perceive it to be the son. However, while talking about their real-life experience, the daughter-in-law percentage rises to $50.2 \%$, a significant jump, while the son retains his status closer to perception with $28 \%$.

$>$ 'Property and inheritance disputes' emerges as the main reason for abuse at 53.2\%. But what is interesting to note, is that $35.7 \%$ feel that 'Attitudinal and relationship issues' is also an important reason.

$>77.6 \%$ of youth feel that the top reason for Elder unhappiness is 'Not being able to spend money as before'. Interestingly, $86.9 \%$ of youth interviewed, advocate 'living in large joint families' as a measure to prevent Elder Abuse, even in today's social scenario of a rising graph of nuclear families. This indicates a tendency to share responsibility jointly, rather than shoulder parental responsibility at the nuclear family level.

The above findings are indicative of the plight that a vast majority of elders face today especially if they are not financially sound. Elderly parents who provide for the financial and personal needs of their family, to the best of their financial means, over an active lifetime often feel let down and depressed, when their sons or daughters do not reciprocate with a sense of responsibility and shirk parental obligations.

Currently, there also appears to be a lack of understanding or consensus between the elders and their children on how to take or share the responsibility of looking after parents and how financial costs for upkeep of the parents or Elderly citizens will be met by the parents/Elderly citizens and their children or legal heirs.

Parents generally have two main options with regard to financial matters. They may choose to maintain control of their wealth and in many instances may not disclose their Will to the children until their death, possibly in order to ensure a loyalty in caregiving. Alternatively, parents may opt to divest or distribute their wealth among their children at some later stage of their lives, with or without negotiating the caregiving responsibilities they expect from their children. Both these approaches leave ample scope for disgruntlement for children in the way they accept or perceive the wealth distribution decision taken by the parent and any bitterness, can become a reason for children evading their parental care responsibility.

When there is a number of children and legal heirs, contrary to the higher prospects of parents getting care, there could be a higher scope for confusion and evading responsibilities in caregiving and taking financial responsibilities of the parents and elders.

Merits of preparing a Will: Many elders miscalculate their post-retirement financial needs. Elders should consciously plan their financial affairs and estimate their wealth to avoid later hardships and undue dependence on family members/others. They should prepare a Will, to document their total wealth, income and intended distribution to children and others after their death. The Will should preferably be registered and spell out the condition or expectation from children singly or jointly, with regard to the care of a spouse. This is a legal document and legal help should be sought to ensure its enforceability in law. The absence of the Will deprives Elders of their lawful right to distribute wealth as they wish. The Elder would then be considered to have died Intestate (without will) and in such cases, distribution will be governed by the respective religious law applicable to them depending on their religion. The Will can be kept confidential and children/legal heirs come to know of their respective share to property only after death and may prevent property disputes, pressuring or emotional blackmailing of parents that adversely impacts caregiving when they need it most. Elderly citizens also have the right to amend their will at any time after preparing or registering it and prior to the death, to accommodate unforeseen situations while bequeathing property (for example, to reallocate shares of heirs/others in the estate to recognize respective roles in care for the parents/elders, than what they had envisaged earlier).

Law for protecting Elders: The Maintenance and Welfare of Parents and Elderly Citizens Act (MWPSCA was enacted in India) in 2007. This Act safeguards Elders by making it obligatory for the children and specified relatives with sufficient means to provide maintenance a monthly subsistence amount for their parents and childless Elderly citizen respectively if the Elder does not have sufficient income for their upkeep.

An Elder can make an application under the Act, to a Maintenance Tribunal set up by the law, which will evaluate the status and pass an appropriate order to provide speedy and effective relief to elderly persons. This 
legislation provides relief to those whose children behave irresponsibly in their obligation to parents as the Act provides for penalties (up to Rs.5000) or imprisonment (up to 3 months) and even taking back ownership of property given away by the parents to their children, if the heir responsible leaves the Elder in any place, with the intention of wholly abandoning him/her. This Act also mandates that States set up old age homes in each district for providing shelter and maintenance to the indigent and destitute Elderly citizens and parents.

Under Section 23, of the Act any Parent or Elderly citizen who has transferred his/her property to children or relatives on the condition that they would provide certain maintenance and amenities to the Elderly citizen but subsequently neglect or refuse to do so, the parents or Elderly citizens can get such transfers voided (canceled) at their option by having such transfer treated as a fraudulent or coercive acquisition and seek return of their property so transferred.

A recently finalized MWPSA (Amendment) Bill 2018 which is now awaiting parliamentary approval has made significant amendments including removal of the existing cap of Rs.10, 000 per month on the maintenance allowance, to make it more in line with the current cost of living and also fair depending on the financial standing of the children. It also aims to widen the definition of "children" under the Act, to include the daughter-in-law, son-in-law, stepson, adopted son and grandchildren, and increasing the punishment for noncompliance to imprisonment up to six months.

Recent research by HelpAge India (2018) indicates that only around 11\% of Elders interviewed were aware of the Maintenance and Welfare of Parents and Elderly Citizens Act, 2007 (MWPSC) Act. There is an urgent need to impart knowledge and ensure that all Elders are aware of their rights under this Act.

As a trendsetter, the Assam government has recently come up with a new legislation Assam Employees Parental Accountability Monitoring Act, 2017 that enables the parents of uncaring and abusive government employees to claim 10\% of the son's/daughter's for their subsistence (Government of Assam, 2017) .

If children do not look after their parents or do not have the means to do so, then it becomes the responsibility of the State to take care of such elders. However, given the means available with the Government and the large population, there are limitations in providing social security and reliable healthcare for all, due to which Elders, especially in the lower strata of society, are prone to suffer more during their old age (Maintenance and Welfare of Parents and Elderly Citizens Act 2007 and MSPSC (Amendment) Bill 2018).

Raising awareness of the MWPSC Act is of crucial importance, as it will be a good means for making children accountable for parental obligations when they are entitled to benefit from the estate assets that devolves to them by inheritance.

\section{Role of daughters in the upkeep of Elders not understood:}

Traditionally in India culture and more specifically in the Indian joint family system, women play pivotal roles in running the family matters including the Caregiving of the Elders. In some communities, women who are "married off" in India, are expected to owe allegiance to their husband's family. Accordingly, they are assumed to take care of their elderly parents-in-law and not necessarily their own parents which is treated as the responsibility of the son/s and daughter/s-in-law. However, in several instances in recent times, there is a lack of clarity on the roles of daughters.

With the decline in the joint family system in India and women becoming professionally and financially independent or aspiring to be so, nuclear families are on the rise and as a consequence, women increasingly absolve themselves from responsibilities of caregiving to elders and hence the role of women whether as daughter or as daughter-in-law in looking after elders can no longer be taken for granted, as envisaged in the past.

Women mostly confine their attention to their husband and children in the typical nuclear family set up and in later years may take responsibilities of grandchildren to temporarily share the responsibilities of their sons/daughters. The role of women in parental care is also governed to some extent, by the religion and sect to which they belong, meaning that different systems prevail among Hindus, Muslims and Christians in this regard and also varies according to the caste and creed among Hindus.

There is an urgent need for women to introspect and to improvise on their role as homemakers for taking care of elders and for sons to play a responsible supportive role by assigning the required priority to the care extended to parents and parents-in-law. Setting some priority to this pressing need of elderly care, improves the respectability of women and they can play a pivotal role in mitigating this problem, which is bound to assume alarming proportions if not adequately addressed. 
The role and commitment of sons, in setting priority and ensuring adequate care for parents and parents-inlaw based on their needs, cannot be overemphasized. The extent of sharing of parental responsibilities between spouses and doing justice to it can prove crucial in inculcating a sense of respect within the family for the elders and also in ensuring the latter's financial, social and psychological well-being. A positive and caring outlook and also a fair sharing of parental responsibilities between siblings, can either help in addressing the above problem or conversely in compounding it. Property disputes and perceived inequity in the distribution of their share of the inheritance, has many times proved the source of discord and resulted in heirs distancing themselves from such responsibilities to elders.

\section{How CSR Can Contribute to Elderly Care}

In India's context, considering the enormity of the Elderly Care need, governmental measures and initiatives need to be supplemented through active support from companies, businesses and other socially responsible sections of society.

Corporate Social Responsibility (CSR) is not a new concept in India. A significant number of Indian companies have long practiced some form of CSR with the broad goal, simply, of contributing to the well-being of the communities they affect and with the intention to give back to society and environment on which they depend. CSR is a commitment to support initiatives that measurably improve the lives of underprivileged by one or more of the focus areas under Section 135 of the Companies Act 2013 and Companies (Corporate Social Responsibility Policy) Rules 2014.

Through the Indian Companies Act 2013, India became the first major country to enact a law making it mandatory for larger and more profitable companies to spend $2 \%$ of their average net profit of three prior financial years on CSR.

Schedule VII of the Companies Act 1956, lists the permissible CSR activities that a company obligated under Section 135 can include in mandatory spending out of net profits. Clause (iii) of the referred Schedule includes setting up old age homes, day care centers and such other facilities for senior citizens (http://corporatelawreporter.com/companies_act/schedule-7-of-companies-act-2013-activities-which-mayme-included-by-companies-in-their-corporate-social-responsibility-policies/).

This offers forward-looking companies, the avenue to play a significant role in Elderly care which does not appear to be sufficiently addressed having regard to the extent and complexity of the problem.

\section{Old Age Homes for Elders including Ex-employees:}

While spending for employees in the guise of CSR is prohibited by the statute, an obligated company may consider setting up and maintaining of old homes, day care centers or related facilities for elders in their area of operation. The beneficiaries can include elders who are retired employees of the Company also as they no longer fall into the category of "employees" and thus improve their image with their workforce of being caring employers.

\section{Engaging services of Elders to strengthen workforce:}

Despite the high rate of unemployment in Kerala, businesses frequently face a shortage of skilled and experienced human resources, especially as the youth population growth in Kerala shows a declining rate mainly due to smaller families and migration from the State. On the other hand, the elderly population has to retire from their jobs, as they reach pensionable age. In India, the pensionable age in government and larger corporations is in the 55-60 range. In comparison, the pensionable age in several western countries is around 70 years. This elderly section comprising those who are professionals or possess specialized skills and experience, present a good opportunity for companies to hire on contractual or part-time basis, due to their availability and willingness to work. Though the Elder category may be considered as a non-productive segment, they could be a good resource to impart skilling for workforces and in advisory and consulting roles. Companies obligated to do CSR may consider this option of hiring the elderly for special and outsourced assignments that can be done without much time pressure, with more flexibility, less supervision and where the output is measurable by quantity rather than by time spent.

CSR projects should be implemented for the elderly, to provide vocational training and promote conditions, so that they can work on flexible terms and apply their skills, knowledge and experience for production of goods or rendering of services and also increase their income where possible and make a social or environmental impact. 
HelpAge India Research Report of 2017 on Elderly Abuse indicates that though there is demand for postretirement work, though not among many Elders. Some relevant findings are as follows:

Demand is more among men (18\%) than women (11\%). In $65-70 \%$ of cases, Elders did not get the job applied for, or could not continue because of adverse circumstances. More specifically, around $66 \%$ and $70 \%$ of elderly males and females respectively, did not get a job mainly because either they did not get a response to their job application or were told they were not eligible for the job due to their age, or were interviewed but did not land a job. Another 25\% Elders who were selected for a job, either did not join or did not continue due to low pay or due to adverse work culture or conditions.

The above statistics indicate that there is a pressing need as well as ample opportunities emerging for Elders especially in states like Kerala, to secure jobs that are flexible in timing, offers suitable work environment and utilizes their skills and experience which would be advantageous to various businesses.

The breakdown of the joint family system and lack of focus on providing for the personal and social needs of this ageing segment in India is another major reason why Elders might prefer to engage in gainful employment whether in regular jobs or self-employment as part of active ageing and to increase their financial sources for subsistence.

It is in the above context, that companies obliged to execute and spend on CSR activity can give serious thought to promote projects involving Elders and ensuring their subsistence and uplift. Elderly Projects can harness the skills and experience of elders to provide stability to teams and blend it with the energy of younger team members.

India has a young population with an average age of 29 years, however, given its demographics as the second most populated country, the elders form a substantial proportion, which is growing at a higher rate and could exert pressure on limited resources, in the coming decades. Employing elders can increase the percentage of the working population and improve contributions to the country's Gross National Product (GNP).

\section{Promoting healthy Ageing}

The Age Watch Index 2015 (HelpAge International, 2015) ranked 96 countries covering 91 percent of the world's population aged 60 years and over. One of the four elements of the index is health status (the others being: income security, capability and enabling environment). India ranks 71 on this index (behind Sri Lanka, Bangladesh and Nepal). Rank of health status for India is particularly low - the lowest in South Asia barring Afghanistan (https://www.ageinternational.org.uk/).

The theme of the World Health Day 2012 was Ageing and Health with a tagline good health adds life to years. WHO's contribution to developing regional strategies for healthy ageing and encouraging healthy ageing initiatives in member states has been significant. WHO (2014) has suggested a Regional Strategy for Healthy Ageing (2013-2018) which seeks to promote care of older persons through the life-course approach

The strategy considers age-friendly primary health care as the cornerstone of healthy ageing when NCDs become more prevalent among older persons. Ageing is among the major contributory factors to the rising incidence and prevalence of NCDs, which in turn are leading causes of preventable morbidity and disability. Participation of the elderly in economic and social activities is also seen as necessary for their overall well-being.

Hence policies and programs that recognize and support the contribution of older men and women, gender equity and special attention to older women who often face greater vulnerability due to life-course experiences are essential elements of healthy ageing.

In the most recent World Health Assembly, WHO offered a multi-sectoral action for life course approach to healthy ageing and suggested a global strategy and plan of action on ageing and health. Healthy ageing is viewed as a process that spans the entire life course and that can be relevant to everyone, not just those who are currently free of disease.

The five proposed strategies (WHO, 2017) are:

$>$ Commitment to action on healthy ageing in every country;

$>$ Developing age-friendly environments;

Aligning health systems to the needs of older populations;

$>$ Developing sustainable and equitable systems for providing long-term care (through home, communities and institutions);

$>$ Improving measurement, monitoring and research on healthy ageing. 
Broadly, healthy ageing would require the establishment of a national framework for healthy ageing, which unfortunately is not emphasized in the new health policy in India. This issue needs to be urgently addressed for the well-being of our Elderly citizens.

Among other things, the WHO strategy also calls for developing an age-friendly environment and fostering of autonomy of older persons, including financial resources and opportunities available for them. There is a need to enhance their engagement in decisions so that they are not left just as passive recipients of welfare. Indian companies can play a key role in supplementing governmental initiatives through CSR projects aimed to engage elders and support healthy ageing for Elders.

\section{Conclusion}

A substantial number of older people in the world today have lived their entire lives in poverty. As they get older, age-related health problems and ageism can make it even more difficult for them to survive. These elders should be helped, no matter what age they are and all right-thinking individuals should join hands and support government, public and private sector initiatives for delivering elderly care where it is needed most.

Elderly citizens comprise a valuable and respected segment of the population and their well-being is of utmost importance for harmonious existence for all societies in the years to come. While a lot needs to be done in this regard, global strategies have to align with country-specific goals to ensure reliable and comprehensive elderly care so that the problems faced by Elders are effectively addressed and their existence is not treated as a burden on society but they retain their rightful status as mentors, guides and active contributors in a country's development and economic growth.

\section{References}

1. Age International Charities, UK. Available at: https://www.ageinternational.org.uk/.

2. Census of India (2011). Available at: http://censusindia.gov.in/2011-provresults/census2011_PPT_paper1.html.

3. Clause (iii), Schedule VII to Section 135 of Indian Companies Act -2013. Available at: http://corporatelawreporter.com/companies act/schedule-7-of-companies-act-2013-activities-which-mayme-included-by-companies-in-their-corporate-social-responsibility-policies/.

4. Fifth Annual Employment-Unemployment Survey (2015). pp. 16. Ministry of Labour \& Employment, Govt. of India, Labour Bureau, Chandigarh. Available at: http://labourbureaunew.gov.in/UserContent/EUS_5th_1.pdf.

5. Government of Assam (2017). Assam Employees Parents Responsibility and Norms for Accountability and Monitoring Act, 2017.

6. HelpAge International (2015). Global AgeWatch Index 2015: Insight report. Available at: http://www.helpage.org/global-agewatch/aabout/global-agewtch-index-version-2015.

7. HelpAge India (2018). ELDER ABUSE IN INDIA - 2018. Available at: https://www.helpageindia.org/wp-content/uploads/2018/06/ELDER-ABUSE-IN-INDIA-2018-AHelpAge-India-report.pdf.

8. Human Development Index Report - United Nations Development Program (UNDP), India. Available at: http://hdr.undp.org/sites/default/files/2016 human development report.pdf.

9. National Health Profile (2017). Available at: http://www.indiaenvironmentportal.org.in.

10.Public Affairs Center (2018). Public Affairs Index 2018. Available at: http://publicaffairsindex.in/.

11.Sample Registration Survey (SRS) based life table 2010-14 of Registrar General of India.

12.Sarkar, S. (2016). Providing Services for Elderly in Rural India - Is Anganwadi Centres a feasible option? International Journal Public Health, 6(2), 57-58.

13.S. Irudaya Rajan - Gayathri Balagopal - Elderly Care in India - Societal and State Responses (2017). Available at: https://www.springer.com/in/book/9789811034381.

14.S. Irudaya Rajan and U. S. Mishra of Centre for Development Studies (CDS). Available at: https://orientblackswan.com.

15.United Nations Population Fund (2017). 'Caring for Our Elders: Early Responses' - India Ageing Report. UNFPA, New Delhi, India. Available at: https://india.unfpa.org/en/publications/caring-our-elders-earlyresponses-india-ageing-report-2017.

16.World Health Organization (2014). Regional Strategy for Healthy Ageing (2013-2018). Multisectoral action for a life course approach to healthy ageing: global strategy and plan of action on ageing and health (2017). Document A69/17.

17.World Health Organization (2014). Regional Strategy for Healthy Ageing (2013-2018). Ageing and health (2018). Available at: http://www.who.int/news-room/fact-sheets/detail/ageing-and-health. 